\title{
Rez. Jewish Art in Its Late Antique Context, edited by Uzi Leibner and Catherine Hezser
}

Uehlinger, Christoph

DOI: https://doi.org/10.1163/15685276-12341564

Posted at the Zurich Open Repository and Archive, University of Zurich ZORA URL: https://doi.org/10.5167/uzh-179656

Journal Article

Published Version

Originally published at:

Uehlinger, Christoph (2020). Rez. Jewish Art in Its Late Antique Context, edited by Uzi Leibner and Catherine Hezser. Numen: International Review for the History of Religions, 67(1):79-92.

DOI: https://doi.org/10.1163/15685276-12341564 
Uzi Leibner and Catherine Hezser (eds.), Jewish Art in Its Late Antique Context

(Texts and Studies in Ancient Judaism 163). Tübingen: Mohr Siebeck, 2016. $\mathrm{x}+382$ pp. ISBN 9783161543883 (hbk.)

The collection of essays published in this volume is an outcome of a joint British-Israeli conference held at the Hebrew University of Jerusalem in December 2014. ${ }^{1}$ The volume's aim is to address Jewish art of late antiquity in multiple contexts and from a variety of perspectives. Of the two conveners and editors, Leibner is a senior lecturer in archaeology at HUJ, Catherine Hezser a professor of Jewish studies at soAs, University of London; contributors include "archaeologists and scholars of rabbinic literature, art historians, and ancient historians, New Testament and patristic scholars" (16) from Britain and Israel. History of religion $\backslash \mathrm{s}$ as another potentially relevant academic discipline goes unmentioned; why then review the book in this journal? Because the topic stands at the crossroads of several issues that should interest our field: Jewish culture and religion is often said to entertain an uneasy relationship with figural art and imagery. This has been effectively deconstructed (Bland 2000) and corrected with regard to ancient Judaism by a plethora of recent studies on Jewish ways of seeing as articulated in rabbinical literature (Neis 2013) and on ancient Jewish visual culture (e.g., Fine 2005, 2013; Levine 2013; most recently, Hezser 2018). Material evidence abounds from all parts of the Roman empire, covering a large variety of artistic and artifact genres, many of them related to special religious concerns and apparatuses, communal ritual and education, religious customs and obligations in private and family life, and burial practices, for example.

It is with regard to the epistemological problem of category formation and disciplinary boundary work that the history of religion $\backslash \mathrm{s}$, which often questions its disciplinary identity and/or transdisciplinary character, might offer some methodological and theoretical tools in order to clarify - and possibly complicate - debates that during more than a century have been largely restricted to the disciplines mentioned in the above-quoted listing. The very definition of "Jewish art" (let alone its historiography, on which see Elsner 2003 and Fine 2013) as against "pagan" or "Christian" art is far from clear, a conundrum

1 I apologize for the delay in producing this review and hope that readers will find useful some references to later publications dealing with the subject. See Bergmeier 2017 for a more timely review. 
that the editors address in their introductory essay: What do scholars mean by "Jewish art" in the first place, and by which criteria should we identify particular works of art as "Jewish?" The option chosen by Hezser and Leibner is to privilege neither content nor any fixed identity, whether ascribed or selfassumed, of commissioners, artists/craftsmen, or consumers, but the archaeological context (especially synagogues and burial sites) in which visual art operated with the specific purpose to represent and identify a community, a place of congregation, a household or an individual as Jewish (p. 2). This said, even at the time when community- and belief-related differentiations became more apparent, distinctively "branded" items (most obviously, the menorah vs. the cross or staurogram) by no means represented the totality of the visual or iconographic repertoire drawn upon; rather, they existed within a considerably larger pool of widely shared, nonexclusive images and symbols. Since Jews, Christians, and "pagans"2 made their selections "from a shared field of artistic and iconographic options available at that time" (p. 13), one might ask whether something like "Jewish practices and agency within late antique visual cultures" (the plural designating different regions within the empire) would not have been a more appropriate - if less succinct — rendering of the subject matter this volume aims to clarify.

The most spectacular finds of "Jewish art" known to date are wall paintings (Dura-Europos) and mosaic floors from late antique synagogues. Many of them excavated in northern Palestine/Israel, these synagogues had been built in or close to towns that also hosted lavishly decorated temples, administrative buildings, and private houses, as well as churches once the empire had become Christian-ruled - material and visual environments with which the Jewish population, among them synagogue leaders and the rabbis, entertained a complex but often cooperative relationship. The entanglement of "Jewish art" with these environments, especially in the context of a growing Christian grip on Palestine (political, administrative, ideological, artistic), is the volume's main subject. In the following, I shall summarize all contributions, comment on aspects that might be of particular interest to historians of religion, and point out instances where a history of religion $\mid \mathrm{s}$ perspective could have, in my view, added to the debate.

2 The latter concept goes unquestioned in the volume under review, which is unfortunate; see Jürgasch 2016. On the persistence of "Paganism" in Christian-ruled Palestine, see Friedheim and Dar 2010; Lavan and Mulryan 2011. 
The editors' introductory chapter conveniently paves the way, starting with terminological and methodological issues: Should scholars privilege patrons' and craftsmen's intentions or processes of reception? In line with recent advances in literary- and art-historical discussions of reception aesthetics and the beholder's active engagement in meaning-making (Elsner 2007), Hezser and Leibner tend to privilege the multiple ways ancient viewers and users would make sense of images (p. 3). I personally value the distinction between production and reception (or consumption) but wonder why we should prioritize the latter over the former. Production of visual artwork, in antiquity no less than today, generally required consciously made decisions; these may have demanded a higher degree of self-reflection than the many possible ways, sometimes vague and thus hard to substantiate, in which ancient viewers would have engaged (if they did so at all) with images (but see below). Dealing with a past society in which "the relationship between visual art, textual traditions, and viewers would have been complex" (p. 3), historians may be tempted to identify with ancient viewers but they cannot be sure whether the interpretive relations they construe, aiming at correlating a maximum of available but always fragmentary sources, are the contexts and intertexts that were important for the ancients.

Another vivid debate in the field concerns the relation of "Jewish art" to the rabbinical literary tradition, on which most reconstructions of late antique Judaism rely. Historians of religion may read this discussion as virtually paradigmatic for the more general question of how they should reconstruct (or construe) ancient religious formations from various bodies of evidence. Reviewing a controversy that tends to be ideological at times, Hezser and Leibner offer a clear exposition of the major positions taken in the debate and, again, take a refreshingly pragmatic stance: "Even if rabbis did not influence synagogue art ... at least some of them would have frequented such synagogues" (p. 12) in which they would have encountered rather lavish visual displays on façades, interior walls, and floors, many of them referring to symbols and motifs they themselves valued highly. If ancient synagogue communities were perhaps no more homogeneous than modern ones, scholars are still better off, I would argue, to allow for a certain variety of responses within late antique Jewish communities. Hezser and Leibner would probably agree that to construe various competing micro-Judaisms systematically opposed to each other seems artificial and unnecessary; instead of producing a sense of diversity, it fixes difference in a rather Procrustean scheme.

The introduction also provides a concise history of recent research in late antique "Jewish art." A number of scholars who have prominently shaped the 
field were among the conference participants and have contributed to the proceedings alongside more junior scholars. Luckily enough, "the authors of the individual contributions differ in their opinions - and the differences were not leveled out by the editors of this volume" (p. 17).

The main body of the volume is divided into four well-balanced parts with three or four contributions each: Part I addresses the development of "Jewish art" in the Roman-Byzantine period. Part II focuses on synagogue mosaic panels and problems of their interpretation. Part III is entitled "Symbols and Iconography." Part IV discusses the relationship between Jewish and Christian art. The four sub-headings point to analytically distinct issues and may have helped to organize the volume; this said, most contributions address issues that range across more than one section.

Opening the section on historical developments, Orit Peleg-Barkat, a classical archaeologist, comments on "art as a means of expressing identity in early Roman Judaea." She concludes that "by the later Second Temple period Jews had developed a collective identity with a significant degree of cultural and religious commonality" (p. 43), considering particularly the controlled use of nonfigurative art as "an important means of expressing ethnic identity" (p. 28). Regrettably she does not offer a sustained discussion of "identity" nor define her own understanding of that concept. Moreover, it remains unclear to this reviewer why and how the artistic motifs she discusses (e.g., rosettes, friezes, pomegranates, and even the menorah) or "a specific local rigid style" (p. 43) she recognizes in Roman-period "Jewish art" should relate to ethnic Jewish identity in the first place.

Lee I. Levine, a leading scholar in "Jewish art" research (see Levine 2013, a truly magisterial work), asks why this art flourished in late antiquity, after the destruction of the Second Temple. He highlights three important factors that provided a new context of challenges and opportunities: the emergence of a new leadership group (the Patriarchate and the Galilean aristocracy), the new political context that allowed for the new leadership's realignment with the Roman imperial government, and the rising prominence of religious art from the 3 rd century onward due to the increasing differentiation (but no less entanglement) of religious communities and traditions evolving to a certain degree in competition to each other: "when the territorial empire of Rome became a religious realm centered in Constantinople, religious identity — Jewish as well as Christian - emerged as a primary factor in Roman society in general and in 
the art of late antiquity in particular" (p. 65). The expression of religious belief through visual art was a largely decentralized process, allowing for a certain diversity and even autonomy of artistic expressions. However, communities with different religious outlooks would have observed each other as they lived alongside each other, with artists sharing both a largely common repertoire and some clearly distinctive, emblematic motifs. "Instances of Jewish creativity in both the material and literary realm can be fully understood and appreciated only if viewed in the wider historical context in which they coalesced, namely, the Byzantine-Christian orbit" (p. 71).

Art historian Peter Stewart turns to one of the best-known among late antique synagogue mosaics, at Beth Alpha in the Beth-Shean valley, discovered as early as 1929 and of major significance to the subsequent development of a Jewish archaeology (on which see Fine 2005). Being particularly interested in matters of style and artistic form, Stewart situates the Beth Alpha mosaics "an extreme case of the disintegration of classical traditions" (p. 82) - within the larger context of "provincialization," a concept that allows scholars to address critically the spatial, temporal, formal, literal, and conceptual distance of particular compositions from the standards of Mediterranean urban centers. Following Italian art historian Ranuccio Bianchi Bandinelli, he suggests that such distance should be viewed as "an epiphenomenon of social changes, reflecting shifts in patronage as provincials and non-aristocrats became the ruling empire" (p. 77). ${ }^{3}$ Comparison of different realizations of similar compositions (such as zodiacs that are or are not synchronized with seasons) supports the hypothesis "that the artists were copying models transmitted by some means or others, but possessed only limited capacity to reproduce them" (p. 79); yet "there is a need for a proper art history of 'incompetence' or of 'amateurism"' (p. 83), since with all its peculiarities, the Beth Alpha mosaic as also "a very impressive work of art, and whatever judgments are made about its formal qualities it is hard to doubt that it must have been successful in meeting the needs of its patrons - the community that paid for it" (p. 84). Since "it is entirely possible that very local concerns, the pressures on local resources or the availability of skilled labour in one place and time, might have impinged decisively on the form of the synagogue mosaic ... the idiosyncrasy of the Beth Alpha mosaic cannot comfortably be explained by religious factors.... Once we move away from the sphere of iconography, the Jewishness of the synagogue mosaics is no longer apparent" (pp. 91-92). From a historian of religion's perspective, Stewart's insistence on what one could label a social and economic

3 Note that while Levine and Stewart are in basic agreement on social-historical processes, they make different use of the term "aristocracy." 
history of artistic agency (cf. Merrony 2013) and his effort not to overemphasize religious distinctiveness as an explanans offer an important corrective to other approaches which tend to stress matters of religion (or "Jewishness," "Christianness," "paganness") in isolation from other aspects of history.

Rina Talgam, also an art historian, has authored one of the rare major publications on late antique mosaics that actively engages with religious studies (Talgam 2014). Her contribution to this volume addresses mosaics and wall paintings as sources for studying ancient Jewish and Christian "attitudes" to figurative art. Mosaics are for obvious reasons much better preserved and documented than wall paintings, but the latter's relative prominence can be hypothesized from literary descriptions (ekphrasis). Joining the debate whether ancient paintings and mosaics illustrated stories or texts, Talgam argues that more often than not, "the pictures required knowledge of Scripture for full comprehension" (p. 102). The matter undoubtedly needs further study, since it can only be decided on the basis of clear-cut criteria, which Talgam does not provide. Regarding differences in attitude between Christians and Jews, Talgam argues that "the choice of the Jews to lower the depiction of images from the wall to the floor was motivated by the risk of venerating the figures" and "another way in which the Jews of that time created a distinction between synagogues and churches, where the biblical images were usually depicted on the walls" (p. 110). Talgam is certainly right in pointing to the different trajectories in the development of vertical imagery in Jewish and Christian tradition, but she may overstress difference, especially with regard to the earlier centuries of the first millennium. Her suggestion to read a famous Talmudic passage (yAbZar 3:3, 42d) as indicating a clear-cut Jewish (rabbinic) preference for mosaics as against wall painting since the early 4 th century CE (106) is questionable; the text hardly supports such a strong, programmatic interpretation and dichotomy.

Archaeologist Ze'ev Weiss, excavator of numerous mosaics in Sepphoris, offers a convenient overview on biblical depictions attested in synagogues and churches of ancient Palestine. Although virtually all evidence comes from mosaics, Weiss (pace Talgam) finds it "conceivable that figurative and biblical scenes graced [the walls of ] ${ }^{4}$ some ancient Palestinian synagogues" (p. 127, referring to the same Talmudic passage). ${ }^{5}$ His study focuses on the "fusion of themes" into "programmatic layouts," distinguishing two different layouts: a well-known tripartite division with biblical themes representing deliverance, the zodiac at its center and references to Temple and Torah at the back; and an-

4 I have supplemented three words without which the sentence would only state the obvious.

5 For wall paintings in the synagogue of Rehov, see Vitto 2015. 
other layout, supported by the more recent findings at Khirbet Wadi Hamam and Huqoq, where multiple biblical scenes (some apparently more narrative than strictly soteriological) surround a central zodiac. ${ }^{6}$ The two traditions coexisted for some time, but Weiss suggests that the midrashic type is earlier and that the later tripartite type reflects increasing conflicts and competition with Christianity, which in Weiss's contribution is strongly characterized as Judaism's rival religion.

Archaeologist Uzi Leibner, who directed the excavations at Khirbet Wadi Hamam from 2007 to 2012, discusses the relationship between synagogue art and rabbinic traditions. He views the mosaics with biblical subject matter found at the Wadi Hamam synagogue (dated late 3rd/early 4th century CE) as a visual kind of aggadic midrash - oral, not necessarily textualized midrash, shared by rabbis and commoners alike. This discussion can now be supplemented by the recently published final excavation report (Leibner 2018).

Roland Deines, a New Testament scholar, returns to the interpretation of the zodiac mosaics and sees the tripartite program (see above, Weiss) as a reference to God's revelation through history (the biblical panel), creation (the zodiac), and the Torah (the "Jewish symbols panel" with the Torah repository). On first sight, this contribution seems to share one of Stewart's more mundane concerns: "one can ... suppose that that those who planned and paid for various parts of the building gave careful consideration to what they were spending their money on" (p. 161). But Deines's interpretations favor a heavily theological approach, postulating no less than a "war of images": the biblical scenes on synagogue floors were

a means to strengthen Israel's identity against Christianity and its usurpation of key Jewish figures and stories.... The interpretive sovereignty over Israel's master narrative was threatened through Christianity's integration of the motifs into its own narrative and Christian rituals and performances in which images play an important part.... In this situation Israel had to win back its interpretive authority over its own Scriptures rather than surrendering the images to others. (p. 180)

It may often be the case that "[a] group under pressure needs to reassure itself about its core beliefs and hopes, and about its modes of knowing it" (p. 181), but in my view, Deines's chapter overinterprets the material and visual evidence.

6 On Khirbet Wadi Hamam, see now Leibner 2018; on Huqoq, see Magness et al. 2014, 2018; Britt and Boustan 2017; Dunbabin 2018. Gittleman 2015 has dealt with both sites comparatively. 
If valid at all, his interpretation would fit the reduced tripartite program much better than the visual midrashim from Huqoq and Wadi Hamam.

Archaeologist Rachel Hachlili, a grande dame in research on Jewish art and ancient synagogues (see Hachlili 2013), contributes a chapter on one of the most prominent Jewish symbols of late antiquity (and beyond), the menorah (on which see now Fine 2016, and Hachlili 2018). "Why did the menorah and not the showbread table evolve into the most important symbol of Judaism," she asks, and offers multiple answers oscillating between symbolism (light, seven branches), cult (continuous use in synagogues, not least in the diaspora), and visual shape (unique, unusual, and easily recognizable). As for the showbread table, one may hypothesize that far less distinctive and ambiguous, it could have been misunderstood as a possible reference to the Christian holy meal and therefore could not serve as a Jewish brand.

Catherine Hezser addresses the well-known debate on how the depiction of the sun god or emblem at the center of a zodiac should be understood when depicted on a synagogue mosaic. In contrast to most earlier attempts, which try to find "the one and only true meaning of the image" (p. 213) - that is, the sun, Helios, an angel, Metatron, or the Jewish god - she prefers an explanation in terms of a Bildfeld allowing multiple interpretations and a range of possible associations depending on a given viewer's "background, socialization, acculturation, and hear-say" (p. 215). Offering a large panorama of ancient speculations about the sun, divine figures in chariots, and heavenly journeys (biblical background, Hellenistic Jewish literature, Greek mythology, and Hellenistic culture, Jewish and Christian sun symbolism in the Roman-Byzantine period), her chapter insists on the "interconnectedness of traditions," on "cultural hybridity," and an "artistic lingua franca," concluding that late antique Christians and Jews may have used similar visual language that still would have expressed competing universal, and thoroughly incompatible, claims.

We are not dealing with the Jewish and Christian adaptation of a 'pagan' image but with the Jewish and Christian use of a common visual language to express their respective theological views ... the representation of the sun was so powerful because it was multivalent: its meaning rested with the individual viewer and depended on his and her background and identity. (p. 233)

Hezser's explanation transcends earlier, somewhat sterile debates about the compatibility (or not) of formerly 'pagan' motifs with rabbinical, or nonrabbinical doctrines and attitudes. It also resonates with much recent research on individuality in lived ancient religion (e.g., Rebillard and Rüpke 2015), a 
research trend that in my view cannot be understood without taking into account the thorough exposure of contemporary scholars to post-modern discourse and the pluralization of truth claims. While I recognize the possibility of ancient individual interpretations even of largely standardized visual compositions, I think the individual-centered approach should be balanced by a critical notion of "interpretive communities."

Contextual concerns with ancient Jewish daily life and the mundane are at the forefront of what is perhaps the book's most innovative chapter, authored by Karen B. Stern, who has recently published an important monograph on ancient graffiti (Stern 2018). Long neglected by "serious" scholarship, graffiti can offer privileged glances into the various ways ancient individuals would have responded to synagogues, catacombs, and other public spaces they visited. The focus here is not on theology, worldviews, symbolism, or authority, but on practices analyzed with the help of practice theory. Of seventy graffiti and dipinti recovered from the walls of the Dura-Europos synagogue, twenty are figurative; they can be understood as responses to what visitors saw on the famous murals, or to the synagogue environment more generally. Similar graffiti can be observed in "pagan" shrines and Christian churches. To Stern, comparison suggests that graffiti "served as a locally and regionally common means for amateur artists - Jews and non-Jews alike - to replicate, reinforce, and visually articulate the devotional spaces and activities that took place in surrounding buildings" (p. 246). Here then (rather than, I would contend, in the well-planned murals and mosaics themselves) do we have some access to ancient individuals and their responses, which, according to Stern, would span from "sheer boredom" to "pure devotion, commemoration, or love" (p. 254). Incidentally, while the analysis of graffiti is certainly sensitive to response theory, the graffiti themselves are products and their authors producers of messages.

In the last part of the book, on the relationship between Jewish and Christian art, history of theology professor Markus Vinzent argues that when viewed sine ira et studio early Christian art is nothing else than Jewish art: "as soon as 'Christian art' of the first two centuries is regarded as Jewish art, both the absence of distinguishable figural and symbolic art in the beginnings and the turn to figural art in the third century finds a match in the 'dramatic and

7 Methodologically speaking, it is striking that Hezser's chapter (in stark contrast to others) focuses on a single motif rather than the larger composition to which it belongs (zodiac and seasons' panels), let alone overall decoration programs. Could it be that except in the case of branding signs (such as a menorah or a cross), individual images may be more variously interpreted when viewed in relative isolation, but that the spectrum of possibles narrows down the more one considers an image in its wider (and actual) pictorial, architectural, and specific, local historical context? 
far-reaching change' [Levine] that occurred simultaneously in Jewish art" (p. 264). This suggestion squares well with the idea of a gradually increasing competition and striving for distinctiveness only in later periods, from the later 4th century onward. "Christian visual engagement with Jewish sacrificial history and the Temple" in late antique Arabia (modern Transjordan) is the subject of historian Sean V. Leatherbury's chapter. His contribution offers an interesting example of how the discussion of "Jewish art" could be disenclosed from exclusive concern with "Jewish art." Theologian Robin M. Jensen studies visual depictions of the three Hebrew youths refusing to venerate King Nebuchadnezzar (Daniel 3) on Christian sarcophagi, and how they relate to Christian attitudes to the Roman imperial cult. To this, Holger Zellentin's study on how the rabbis viewed the imperial cult's Christianization provides a convenient complement from a different angle. As "post-Constantinian rabbis would have had even more reason to focus on the imperial cult than their peers under pagan Rome ... the Yerushalmi's specific changes to the laws of idolatry reflect the Christianisation of the imperial cult" (p. 334). This last contribution is concerned with changing rabbinical views on idolatry rather than with Jewish art in its late antique context. Rather surprisingly, no attempt is made to relate the two topics in a way or another, not even by considering idolatry discourse as visual art's "other side of the coin."

Jewish Art in Its Late Antique Context can be highly recommended to historians of religion on several grounds. It offers important discussions of material that no serious historical study of late antique religion $\mid$ s should ignore. Providing a wealth of insights into provinces of ancient religion where some of us would perhaps not have suspected the existence of full-fledged religionwith-community-related visual arts, the book is a strong (if unintentional) testimony to the validity of the Visible Religion paradigm (on which see Uehlinger 2015): Religious traditions ancient or modern are better understood once we take into account their visual culture. Consequently, the various ways religious groups and institutions articulate their worldview and self-understanding within society at large by drawing on and selecting from collective visual repertoires should be a mandatory object for the study of ancient and contemporary religion alike.

The volume also raises the question of the relationship between our discipline (the study of religions at large, or history of religion more narrowly understood) and specialized research focusing on one or another religious tradition such as ancient Judaism or ancient Christianity. In my own view, the 
academic quality of our discipline depends vitally on the acknowledgment of and critical engagement with specialized debates such as the ones documented in this volume. ${ }^{8}$ To anyone interested in late antique visual culture and religion, Jewish Art in Its Late Antique Context offers a rare, up-to-date compendium of data, research questions, debates and positions on many crucial issues regarding not only "Jewish art," but also the latter's place within the "cumulative aesthetics" (Elsner 2004) of late antiquity.

Could the volume have benefited from interaction with the one discipline it apparently ignores: history of religion $\mid s$ ? Disregarding the conflict of interest I may have when answering this question, I am convinced that the disciplines represented in the volume and their interdisciplinary exchange might indeed have benefited from a "relative outsider's" perspective for a number of reasons. First, an outsider will probably recognize more easily how much the discourse and arguments of this or that contributor are shaped by his or her discipline's largely implicit assumptions, explicit terminologies, and epistemic blinkers. An outsider will notice more easily that the volume's contributors will at times use the same or similar concepts but attribute significantly different meanings to them. Reading the book from a distance, one may appreciate it as an example of how category formation operates in historical scholarship, and as a witness to the critical need to advance beyond disciplinary comfort zones. The editors' aim to question well-established dichotomies and borderlines between reified religious traditions is certainly one of the volume's special merits. Their will to contextualize whatever material, visual, and literary evidence they address is another important quality. What the volume may not yet have managed to achieve is to reframe its ultimate object of inquiry: Neither Jewish nor Christian art, nor survivals of "pagan" symbolism in the former or the latter are what historians of late antique religion should eventually look for. The primary object of our inquiry should be the "cumulative aesthetics" already mentioned, within which patrons and artists operated by selections, some of which (but certainly not all) were defined by religious concerns. What we need to better understand is how groups and individuals positioned themselves in the various local and regional concretions of the plural yet powerfully structured fabric of late antique society. Whether and to what extent their "Jewishness" (or any other religious identity) determined their choices cannot be taken for

8 It would be worthwhile to compare the processes discussed in this volume to the transition of earlier, purportedly "aniconic" (but see Huntington 2015), to later figurative forms of Buddhist visual culture. Leibner and Hezser provide an example and set a standard how such a study would have to combine the potential insights of archaeology, art history, and literary studies. 
granted a priori but needs to be demonstrated hands-on through the combination of critical engagement with material data on the one hand, and the self-critical, reflective use of terminology and historiographical models on the other hand.

In contrast to some of the contributors to the volume under review, historians of ancient religion do not postulate an a priori commonality or collective identity of Jews vs. Christians (or "pagans," for that matter). Instead, we endeavor to get a better grasp of multiple coexisting identities (Rebillard 2012) and religio-historical dynamics: What were the ideological and practical, political and economic latitudes a patron would have had when commissioning some new decorum for a synagogue or church, or (more often) one or another part of it? What were the economic, artistic, and practical latitudes of craftsmen no theologians after all — involved in the production of buildings, murals, mosaics, etc.? In what multiple ways late antique men and women would have experienced these enhanced communal spaces when gathering there for conspicuous ritual consumption? Leibner and Hezser are to be congratulated for a volume that does not answer these questions, but challenges us to continue asking them in a theoretically sophisticated manner.

\author{
Christoph Uehlinger \\ University of Zurich \\ Christoph.Uehlinger@uzh.ch
}

\title{
References
}

Bergmeier, Armin. 2017. Review of Leibner and Hezser (eds.), Jewish Art in Its Late Antique Context. Plekos 19: 119-125. URL: http://www.plekos.uni-muenchen.de/ 2017/r-leibner-hezser.pdf.

Bland, Kalman P. 2000. The Artless Jew: Medieval and Modern Affirmations and Denials of the Visual. Princeton, NJ: Princeton University Press.

Britt, Karen and Ra'anan Boustan. 2017. The Elephant Mosaic Panel in the Synagogue at Huqoq: Official Publication and Initial Interpretations (Journal of Roman Archaeology, Supplement 106). Portsmouth, RI: Journal of Roman Archaeology.

Dunbabin, K. M. D. (ed.). 2018. "The Elephant Mosaic Panel at Huqoq: Book Reviews and Further Interpretations." Journal of Roman Archaeology 31(2): 506-558.

Elsner, Jaś. 2003. "Archaeologies and Agendas. Reflections on Late Ancient Jewish Art and Early Christian Art." Journal of Roman Studies 93: 114-128. 
Elsner, Jaś. 2004. "Late Antique Art: The Problem of the Concept and the Cumulative Aesthetic." In Simon Swain and Mark Edwards (eds.), Approaching Late Antiquity: The Transformation from Early to Late Empire, Oxford: Oxford University Press, 271-309.

Elsner, Jaś. 2007. Roman Eyes: Visuality and Subjectivity in Art and Text. Princeton, NJ: Princeton University Press.

Fine, Steven. 2005. Art and Judaism in the Greco-Roman World: Towards a New Jewish Archaeology. Cambridge: Cambridge University Press.

Fine, Steven. 2013. Art, History and the Historiography of Judaism in Roman Antiquity (The Brill Reference Library on Judaism 34). Leiden: Brill.

Fine, Steven. 2016. The Menorah: From the Bible to Modern Israel. Cambridge, MA: Harvard University Press.

Friedheim, Emmanuel and Simon Dar. 2010. "Some Historical and Archaeological Notes about Paganism in Byzantine Palestine." Revue Biblique 117(3): 397-409.

Gittleman, Elena. 2015. "Judging Samson: The Synagogue Floor Mosaics of Horvat Huqoq and Khirbet Wadi Hamam." Unpublished M.A. thesis, Southern Methodist University, Dallas, TX.

Hachlili, Rachel. 2013. Ancient Synagogues - Archaeology and Art: New Discoveries and Current Research (Handbook of Oriental Studies I/105). Leiden: Brill.

Hachlili, Rachel. 2018. The Menorah: Evolving into the Most Important Jewish Symbol. Leiden: Brill.

Hezser, Catherine. 2018. Bild und Kontext. Jüdische und christliche Ikonographie der Spätantike (Tri Corda. Jenaer Vorlesungen zu Judentum, Antike und Christentum 11). Tübingen: Mohr Siebeck.

Huntington, Susan L. 2015. "Shifting the Paradigm: The Aniconic Theory and Its Terminology." South Asian Studies 31(2): 163-186.

Jürgasch, Thomas. 2016. "Christians and the Invention of Paganism in the Late Roman Empire." In Michele R. Salzmann, Marianne Sághy, and Rita L. Testa (eds.), Pagans and Christians in Late Antique Rome: Conflict, Competition, and Coexistence in the Fourth Century, Cambridge: Cambridge University Press, $115^{-138 .}$

Lavan, Luke and Michael Mulryan (eds.). 2011. The Archaeology of Late Antique 'Paganism' (Late Antique Archaeology 7). Leiden: Brill.

Leibner, Uzi. 2018. Khirbet Wadi Hamam: A Roman-Period Village and Synagogue in the Lower Galilee (Qedem Reports 13). Jerusalem: Israel Exploration Society.

Levine, Lee I. 2013. Visual Judaism in Late Antiquity: Historical Contexts of Jewish Art. New Haven, CT: Yale University Press.

Magness, Jody, Shua Kisilevitz, Karen Britt, Matthew Grey, and Chad Spigel. 2014. "Huqoq (Lower Galilee) and its Synagogue Mosaics: Preliminary Report on the Excavations of 2011-13." Journal of Roman Archaeology 27(1): 327-355. 
Magness, Jody, Shua Kisilevitz, Matthew Grey, Dennis Mizzi, Daniel Schindler, Martin Wells, Karen Britt, Ra'anan Boustan, Shana O'Connell, Emily Hubbard, Jessie George, Jennifer Ramsay, Elisabetta Boaretto, and Michael Chazan. 2018. "The Huqoq Excavation Project: 2014-2017 Interim Report." Bulletin of the American Schools of Oriental Research 380: 61-131.

Merrony, Mark. 2013. Socio-Economic Aspects of Late Roman Mosaic Pavements in Phoenicia and Northern Palestine (BAR International Series 2530). Oxford: Archaeopress.

Neis, Rachel. 2013. The Sense of Sight in Rabbinic Culture. Jewish Ways of Seeing in Late Antiquity (Greek Culture in the Roman World). Cambridge: Cambridge University Press.

Rebillard, Eric. 2012. Christians and Their Many Identities in Late Antiquity, North Africa, 200-45o CE. Ithaca, NY: Cornell University Press.

Rebillard, Eric and Jörg Rüpke (eds.). 2015. Group Identity and Religious Individuality in Late Antiquity (CUA Studies in Early Christianity). Washington, DC: The Catholic University of America Press.

Stern, Karen. 2018. Writing on the Wall: Graffiti and the Forgotten Jews of Antiquity. Princeton, NJ: Princeton University Press.

Talgam, Rina. 2014. Mosaics of Faith. Floors of Pagans, Jews, Samaritans, Christians, and Muslims in the Holy Land (Treasures of the Past). Jerusalem: Yad Ben-Zvi.

Uehlinger, Christoph. 2015. "Approaches to Visual Culture and Religion: Disciplinary Trajectories, Interdisciplinary Connections, and Some Conditions for Further Progress." Method \& Theory in the Study of Religion 27(4-5): 384-422.

Vitto, Fanny. 2015. "Wall Paintings in the Synagogue of Rehov: An Account of Their Discovery." Israel Museum Studies in Archaeology 7: 2-13. 